\title{
The Effect of Chayote Juice (Sechium Edule) to Reduce Blood Pressure in Elderly with Hypertension
}

\author{
1st Hikmah \\ Midwifery Study Program \\ The Health Science Faculty, \\ Muhammadiyah Tangerang University \\ hikmah@umt.ac.id \\ 4th Sifaunnisah \\ Nursing Professional Education Study \\ Program The Health Science Faculty, \\ Muhammadiyah Tangerang University
}

\author{
2nd Hera Hastuti \\ Nursing Professional Education Study \\ Program \\ The Health Science Faculty, \\ Muhammadiyah Tangerang \\ University
}

\author{
3rd Eka Mardiana \\ Midwifery Study Program The \\ Health Science Faculty, \\ Muhammadiyah Tangerang \\ University
}

\begin{abstract}
Hypertension often occurs in the elderly due to hormonal changes after menopause. Treatment of hypertension can be done non-pharmacologically by consuming chayote. This study was to explore the effect of chayote juice on blood pressure in elderly people with hypertension at Puskesmas (Community Health Center) Teluknaga. This is a auasiexperimental research design with pre-test and post-test without control. 13 respondents were sample of this study taken with non-random metode consecutive sampling. Bivariate analysis was processed with Wilcoxon Match Pair Test. The analysis results with the range of age 60-70 (92.3\%) and age 75-90 (7.7\%) with females (84.6\%) and male (15.4\%) shows that median decrease in systolic blood $30.00 \mathrm{mmHg}$ and diastolic $10.00 \mathrm{mmHg}$. It was obtained $p$ value $0.001<a 0.05$. in conclusion, the chayote juice has effects to reduce blood pressure in elderly with hypertension. The elderly and families are expected to apply independently by consuming chayote juice which aims to maintain and control blood pressure. Keywords: blood pressure, chayote juice, elderly, hypertension.
\end{abstract}

\section{INTRODUCTION}

According to Government Regulation No. 43 2004, the elderly is a person who has reached the age of 60 years or more. Elderly is a universal process that occurs from the moment a person is born. In 2015 there were 901,000,000 people aged 60 years or more, consisting of 12 percent of the global population [1]. The elderly population in Indonesia reached 20.24 million, equivalent to 8.03 percent of the population in Indonesia. Banten Province has a population aged over 60 years with 488,243 inhabitants. Elderly prevalence in Tangerang in 2014 were 65,324 males and 69,857 females [2].

The heart in the elderly will generally be enlarged. It will relate to abnormalities in the cardiovascular system causing interference on blood pressure such as hypertension [3]. Hypertension is a systolic blood pressure that exceeds $140 \mathrm{mmHg}$ and a diastolic blood pressure of more than $90 \mathrm{mmHg}$. Year by year, there was an increase in the prevalence of hypertension sufferers along with increasing life expectancy, obesity population and public awareness of this disease [4]. According to the World Health Organization [5] The prevalence of hypertension around the world reaches one billion. The highest disease in the elderly in Indonesia based on Basic Health Research (2013) was hypertension with a prevalence of $45.9 \%$ at the age of 55-64 years, $57.6 \%$ at the age of 65-74 years, and $63.8 \%$ at the age of $\geq 75$ years [6].

Hypertension can be overcome in two ways, namely by pharmacology and non-pharmacology ways. Herbs needed for high blood pressure are fruits, vegetables containing potassium, one of vegetables that contains potassium is chayote or sechium edule in latin. Potassium is useful for the body to control blood pressure as high blood pressure therapy and to cleanse carbon dioxide in in the blood. Potassium is also useful for triggering the work of muscles and nerve nodes. High potassium will facilitate the delivery of oxygen to the brain and help to maintain the fluid balance, so that the body becomes fresher. People with high blood pressure are encouraged to consume chayote regularly [7]. Potassium-rich fruits and vegetables can lower blood pressure and improve blood vessel function [8].

The fruits and vegetables that have potassium content are watermelon $(82 \mathrm{gr} / 100 \mathrm{mg})$, Papaya $(257 \mathrm{mg} / 100 \mathrm{gr})$, cucumber $(73 \mathrm{mg} / 100 \mathrm{gr})$, chayote $(365 \mathrm{mg} / 100 \mathrm{gr})$, Tomato (360 gr/100 mg), starfruit (207 mg/100 gr), Banana (358 mg/100 gr). [9]. Non-pharmacological therapy that has a high potassium content is chayote. Besides, it has no side effects, cheap price, and easy to get. In addition, it is Sudanese's favorite vegetables. Seldom have the researchers studied chayote to lower high blood pressure in the elderly. Teluknaga has a fertile soil seen from the numbers of farmers planting chayote. Therefore, the researchers prefer the chayote to be used for the research.

Chayote is proven to reduce high blood pressure, the results of research conducted by Djaelani in PSTW of Budi Luhur Kosongan, Bantul, Yogyakarta. He found differences in systolic and diastolic pressure before and after consuming chayote juice. The blood pressure of hypertension sufferers felt after consuming chayote for five days in a row, with the frequency of taking chayote once a day (122 grams) with boiled water $(180 \mathrm{~m})$. Chayote juice was influential to reduce blood pressure in elderly people with hypertension [10]. Based on the results of interviews on March 18, 2018 with five elderly hypertension sufferers in Puskesmas (Community Health Center) Teluknaga as research setting, the researcher found that 3 sufferers with hypertension did not know that chayote could reduce high blood pressure. 
They rarely consumed cooked chayote and never consumed chayote juice. two elderly hypertension sufferers knew that chayote could reduce high blood pressure, often consumed chayote made of vegetables, but never consumed chayote juice. To reduce blood pressure they usually consumed star fruit juice.

\section{MethodolOGY}

The research design used in this study was quasi experiment with pre test and post test without control. In the design, the researchers intervened one group without a comparison group. Treatment effectiveness was assessed by comparing the value of the post test and the pre test [11].

The population used in this study were all elderly with hypertension (360 people) at Puskesmas Teluknaga, to become respondents by filling out and signing a given informed consent sheet. While the exclusion criteria were the elderly who had complications, were not ready to be respondents.

To maintain the safety of respondents, the ethic test had been conducted. This research had passed the ethics number 445/094 - KEP-RSUDTNG and this research adhered to the principles of ethics autonomy, beneficence, confidentiality, justice, veracity and fidelity.

The tools and materials used to collect data are spygmomanometer to measure systolic and diastolic blood pressure, stethoscope to find out the pulse at the time of blood pressure measurement. Sphygmomanometer and stethoscope used were already calibrated, knife to peel chayote, vegetable scales to weigh the chayote (122 grams), boiled water $(180 \mathrm{ml})$ by using measuring cups, disposable plastic cups, a blender to make juice, and forms (respondents' characteristic forms, pre-test and post-test sheet).

The procedure in this research was that the researchers conduct a pre-test by measuring blood pressure a day before giving chayote juice. Researchers made chayote juice by peeling and washing raw chayote, researchers weighed the peeled and washed 122 grams of chayote, prepared $180 \mathrm{ml}$ of plain water, and put them into a blender to blend until smooth, poured the blended chayote into a plastic. Researchers visited the respondent's house at 10 a.m. to give the chayote juice. The chayote juice was taken two hours or an hour before the meal. The researchers gave the chayote juice using cups and waited the respondent took the chayote juice. Respondents were given chayote juice for four consecutive days. Then post- test by measuring blood pressure after 4 days of intervention. Researchers compare pre-test and post test results after the intervention of giving chayote juice. The researchers also taught the respondents and families how to make the chayote juice.

The analysis techniques used in this research were the analysis of univariate and bivariate. A univariate analysis of the study was used to describe the characteristics of the respondent's age and gender, and look for mean of blood pressure before and after drinking chayote juice. Bivariate
Tangerang. This study used non probability sampling techniques (non-random samples) with the consecutive sampling method, a method of selection of samples conducted by selecting all the individuals found and meeting the selection criteria, until the number desired sample is met.

The sample size of this study was taken by the test of two difference means of independent groups. It was obtained the sample of 13 respondents. The selection of samples was based on the inclusion criteria of the elderly diagnosed with hypertension by doctors, aged $\geq 60$ years. The criteria were elderly who did not routinely consume hypertension drugs and did not consume hypertension drugs during drinking chayote juice, were fond of consume chayote juice, were available to

analysis was used to test the effect of both variables using the Shapiro-Wilk test and the Wilcoxon Match Pair Test.

\section{FINDINGS AND DISCUSSION}

The following will describe the results of univariate and bivariate data in the form of the following table : Table 1. Frequency distribution of Elderly With Hypertension Based on Respondent Characteristics

\begin{tabular}{lcc}
\hline $\begin{array}{l}\text { Characteristics } \\
\text { Respondents }\end{array}$ & Frequency & $\%$ of \\
\hline Age & & \\
$60-74$ & 12 & 92,3 \\
$75-90$ & 1 & 7,7 \\
Gender & & \\
Male & 2 & 15,4 \\
Female & 11 & 84,6 \\
Total & 13 & 100 \\
& & \\
\hline
\end{tabular}

Based on the results of data analysis, the majority of respondents' age range was elderly 60-70 years (92.3\%). This was in line with previous research conducted by Djaelani that frequency distribution based on the age of respondents experiencing hypertension were more at Elderly age 60-70 years, namely 12 respondents $(70.6 \%)$ [9]. It is in accordance with the theory expressed by Donlon that the higher the age the higher the risk of hypertension. The risk of hypertension is caused by the aging process of the cardiovascular system [12]. After 45 years old, arterial walls will undergo thickening due to the accumulation of collagen substances in the muscle layer, so that the blood vessels will gradually narrow and become stiff [13].

Based on the results of data analysis, the majority of elderly with hypertension were female of 11 respondents $(84.6 \%)$. The sex factor was influential in the occurrence of hypertension. A young age under 60 years old, male are more suffered from hypertension than that of female. Male 
allegedly have lifestyles that tend to increase blood pressure than that of female. However, after entering the menopause, the prevalence of hypertension in female increases.[14]. The tendency of women to experience hypertension at menopause due to a decrease in the hormone estrogen. Decreased estrogen levels tend to decrease HDL levels, increase LDL and cholesterol in the blood. Along with the increase in cholesterol in the blood, it is very susceptible to atherosclerosis which clogs the blood flow resulting in hypertension [15]. This process continues where the estrogen hormone changes its quantity according to the age of the woman naturally, which generally begins to occur in women aged 45-55 years before aging [16].

Table 2. Distribution of Frequency of Elderly People with Hypertension Based on Measurement Blood Pressure before and after Drinking Chayote Juice $(\mathrm{N}=13)$

\begin{tabular}{lcccc}
\hline \multicolumn{1}{c}{$\begin{array}{c}\text { Blood } \\
\text { pressure }\end{array}$} & $\begin{array}{c}\text { Media } \\
\text { n }\end{array}$ & $\begin{array}{c}\text { Standard Minimal } \\
\text { deviation }\end{array}$ & Maximal \\
\hline $\begin{array}{l}\text { Sistolik } \\
\text { Pre }\end{array}$ & 160 & 9,541 & 150 & 170 \\
Intervensi & $\mathrm{mmHg}$ & & $\mathrm{mmHg}$ & $\mathrm{mmHg}$ \\
Post & 130 & 10,919 & 120 & 150 \\
Intervensi & 130 & & $\mathrm{mmHg}$ & $\mathrm{mmHg}$ \\
Diastolik & $\mathrm{mmHg}$ & & & \\
$\begin{array}{l}\text { Pre } \\
\text { Intervensi }\end{array}$ & & 4,804 & 90 & 100 \\
Post & $90 \mathrm{mmHg}$ & 2,774 & 80 & $\mathrm{mmg}$ \\
Intervensi & & & $\mathrm{mmHg}$ & $\mathrm{mmHg}$ \\
& $80 \mathrm{mmHg}$ & & & $\mathrm{mmg}$ \\
\hline
\end{tabular}

Table 2 shows that the median of systolic blood pressure before being given chayote juice is $160 \mathrm{mmHg}$ and the diastolic blood pressure has a median value of $90 \mathrm{mmHg}$. After the intervention of giving chayote juice, it was obtained the median of systolic blood pressure is $130 \mathrm{mmHg}$ and the median diastolic blood pressure is $80 \mathrm{mmHg}$. Based on the analysis of the data, it shows that the systolic value gets a decrease of $30.00 \mathrm{mmHg}$ and the diastolic gets a decrease of $10.00 \mathrm{mmHg}$.

Table 3

Wilcoxon Match Pair Test Stats Test Results

\begin{tabular}{ccc}
\hline Test Statistik & $\begin{array}{c}\text { Pre and Post } \\
\text { Test Sistolik }\end{array}$ & $\begin{array}{c}\text { Pre and PostTest } \\
\text { Diastolik }\end{array}$ \\
\hline P value & 0,001 & 0,001
\end{tabular}

The results of statistical tests using the Wilcoxon Match Pair Test, systolic pre-test and the post systolic were obtained $\mathrm{P}$ value of 0.001 , and pre-test and post-test diastolic test were obtained $\mathrm{P}$ value of 0.001 which means that Ha was accepted, in conclusion, that there were significant changes before and after giving of chayote juice on blood pressure of elderly with hypertension at Puskesmas Teluknaga.

The results shows that the median systolic and diastolic blood pressure in elderly with hypertension before being given chayote juice in is $160.00 \mathrm{mmHg}$ and the diastolic blood pressure has a median value of $90.00 \mathrm{mmHg}$. After the intervention of giving chayote juice it was obtained that the median systolic blood pressure was $130.00 \mathrm{mmHg}$ and the median diastolic blood pressure was $80.00 \mathrm{mmHg}$. Based on the analysis of the data, it shows that the systolic value gets a decrease of $30.00 \mathrm{mmHg}$ and the diastolic gets a decrease of $10.00 \mathrm{mmHg}$.

Decreased blood pressure is supported by epidemiological studies that have shown that populations or individuals accustomed to high potassium intake have lower blood pressure levels and have a very low incidence of hypertension and associated blood vessels when compared to populations or individuals having low potassium intake [17]. This is in accordance with the theory that chayote can reduce blood pressure because chayote contains potassium [8].

Chayote contains potassium and alkaloids which are diuretic, which helps the kidneys remove excessive fluid and salt from the body, so that less fluid in the blood will reduce blood pressure. Fruit and shoots of chayote are diuretic (smooth out urine). The efficacy of this diuretic, will have an impact on decreasing high blood pressure (hypertension), preventing hardening and calcification of arteries, reducing the possibility of heart attack and dissolving kidney stones [18]. Chayote juice also has a diuretic effect which causes the salt content in the blood to decrease. This process helps absorb or retain water, thereby reducing the work of the heart in pumping blood and lowering blood pressure. In addition, this diuretic effect can facilitate the discharge of urine [19].

The results of statistical tests using the Wilcoxon Match Pair Test, the post systolic systolic pre-test obtained a $\mathrm{P}$ value of 0.001 , and the post-test diastolic diastolic test obtained a $\mathrm{P}$ value of 0.001 which means $\mathrm{Ha}$ was accepted, it can be concluded that there were significant changes before and after administration of chayote juice on blood pressure in elderly hypertensive patients in Puskesmas Teluknaga. This is in line with Djaelani's study In statistical tests using the Non Paramertic Wilcoxon Match Pair Test, obtained by Asym. Sig. (2-tailed) of 0,000 ( $\mathrm{p}$ value). Determining whether the hypothesis accepted or rejected is by comparing the value of the significance level (p) with the error rate of $5 \%(0.05)$ when $\mathrm{p}$ is greater than 0.05 , the hypothesis is rejected and when $\mathrm{p}$ is smaller than 0.05 then the hypothesis is accepted. The calculation results obtained $\mathrm{p}$ value of $0.000<0.05[10]$.

The study was in accordance with Wati's research entitled "The Effect of Chayote Juice on Changes in Blood Pressure in Hypertensive Patients in Krajan Hamlet, Nyatnyono Village, Ungaran Barat". Test analysis used was Mann Withney. The results showed that there was an effect of squash juice on changes in blood pressure in patients with hypertension in Krajan Hamlet, Nyatnyono, Ungaran Barat (p-value systole was 0.029 and diastolic was 0.002)[20]. Therapy for chayote juice can be used as an appropriate and practical alternative treatment without side effects [21].

This is in accordance with the theory that chayote can reduce blood pressure because chayote contains potassium [8]. Potassium is a mineral that is good for reducing or 
controlling tension. Potassium is a strong diuretic that helps maintaining water balance, blood pressure, acid-base balance, expedites urine release, helps dissolve stones in the urinary tract, bladder and kidneys. Potassium is also very important in converting blood sugar into muscle sugar [22].

\section{CONCLUSION}

The result shows that there was an effect of consuming chayote juice on blood pressure in the elderly with hypertension at Community Health Center of Teluknaga. Which means consuming chayote juice effectively reduces systolic blood pressure $30 \mathrm{mmHg}$ and diastolic $10 \mathrm{mmHg}$. It is based on the measurement of blood pressure before the intervention, a systolic median value was $160 \mathrm{mmHg}$ and a diastolic median value was $90 \mathrm{mmHg}$. After the intervention, it was obtained that a systolic median value was $130 \mathrm{mmHg}$ and diastolic was $80 \mathrm{mmHg}$. Suggestions for the elderly are expected to apply independently by consuming chayote juice, which aims to maintain and control blood pressure. For family, it is expected to motivate and help elderly in consuming chayote juice and maintain elderly health by regulating lifestyle, food, and stress. For further research, it is expected to be able to develop research related to this study.

\section{REFERENCES}

[1] United Nations Population Division, World Population Prospects, The 2015 Revision, United Nat. New York, 2015.

[2] Tangerang District Health Office, Tangerang District Health Profile. 2014.

[3] Fatimah, Elderly Nutrition. Jakarta: Erlangga, 2010.

[4] Mohani, "Hipertensi primer In: internal medicine textbook", VI., vol. 2. Jakarta: Interna Publishing, 2014.

[5] WHO, "Global Hypertension Data.” 2013.

[6] "Ministry of Health of the Republic of Indonesia, Data and Information (Indonesian Health Profile)." 2014.

[7] N. Aini, The Enormity of Herbal and Yoga, Real books. Yogyakarta, 2015.

[8] and T. A. B. S. S. E. Berry, U. Z. Mulla, P. J. Chowienczyk, "Increased potassium intake from fruit and vegetables or supplements does not lower blood pressure or improve vascular function in UK men and women with early hypertension: A random ... Increased potassium intake from fruit and vegetables or supplements d," 2010.

[9] S. Wibowo, Suppression of various kinds of diseases, Jakarta : Pustaka Makmur, 2015.

[10] P. Djaelani, "Effect of chayote juice on changes in blood pressure in elderly patients with hypertension in PSTW Budhi Luhur Kasongan Bantul Yogyakarta," 2015.

[11] K.K Dharma, Nursing Research Methodology. Jakarta: Trans Info Media, 2011.

[12] B, Darmojo, Geriatric Textbook (Elderly Health Sciences), 3rd Edition, Jakarta : Balai Pustaka, 2006.
[13] Anggraini, et.all, "Factors related to the occurrence of hypertension in patients treating at the adult clinic in Bangkinang Health Center for the period of January to June 2008," Pekanbaru Riau:Faculty of MedicineUniversity Riau, 2009.

[14] Ministry of Health of the Republic of Indonesia, Technical Guidelines for Finding and Managing Hypertension, Jakarta: Directorate of Control of NonCommunicable Diseases, 2006.

[15] E. Wirakusumah, Nutrition Tips and Solutions for Staying Healthy, Beautiful and Happy in the Period of Menoupouse with Natural Extrogen Therapy. Jakarta: Gramedia Pustaka Utama, 2004.

[16] and E. A. R. Letters, R. C. Trial, L. Modification, "Effects of comprehensive lifestyle modification on blood pressure control," 2009.

[17] D. J. Naismith and A. Braschi, "The effect of low-dose potassium supplementation on blood pressure in apparently healthy volunteers," pp. 50-60, 2018.

[18] A. Sudibyo, "Effects of chayote juice (sechium edule swartz) on normal male blood pressure," Journal: Muhammadiyah University Surakarta," vol. 1, 2014. [19] F. Rizki, The Miracle of Vegetable. 2013.

[20] D. R. Wati, "Effect of chayote squeeze on changes in blood pressure in patients with hypertension in Krajan Hamlet," 2012.

[21] T. Thenappan, M. L. Ormiston, J. J. Ryan, and S. L. Archer, "Pulmonary arterial hypertension : pathogenesis and clinical management," no. fig 1 , 2018.

[22] I. Junaidi, Hypertension Introduction to Prevention and Treatment. Jakarta: PT. Bhuana Ilmu Populer, 2010. 